\title{
Overcoming Photo Degredation in Dye Sensitized Solar Cell
}

\author{
Odeyemi Charity Segun*1, Awodugba ${ }^{2}$, Ayodeji Oladiran ${ }^{3}$ \\ ${ }^{1}$ Department of Electrical Electronics Engineering, Federal University of Technology P. M. B 704, Akure, Nigeria \\ ${ }^{2,3}$ Department of pure and Applied Physics, Ladoke Akintola University of Technology Ogbomoso Nigeria
}

\begin{tabular}{l}
\hline \hline Article Info \\
\hline Article history: \\
Received Jan 2, 2018 \\
Revised Jan 19, 2018 \\
Accepted Feb 2, 2018
\end{tabular}

Keyword:

Mordant

Photons

Sensitizer

Stability

Titanium dioxide

\begin{abstract}
Dye sensitized solar cell (DSSC) is a thin film solar cell which has prospect for solving the fast growing global energy demand. It uses basically titanium dioxide $\mathrm{TiO} 2$, organic dye and electrolyte. The availability of these materials and their low cost makes DSSC the cheapest solar cell in the world. Although efforts are being made to improve efficiency but the short life span remain a major challenge. Improving this short life span is what this study is responding to. A known method of preparation was examined and modified for better DSSC performance. Two new approaches were introduced to the process of DSSC fabrication: the introduction of a mordant and sealing the edges. The organic pigment used for light harvesting was Teak dye. The results of the conventional method and the modified method were obtained and compared. The results of the newly developed method show a very wide improvement in the DSSC life span, and even some improvement in the efficiency. The active period of the cell increase to 60 days while the one made with the conventional approach degraded after four hours. Through these modifications, a new procedure for producing DSSC has been developed which will solve the problem of short active period in dye sensitized solar cell.
\end{abstract}

Copyright $\odot 2018$ Institute of Advanced Engineering and Science.

\section{Corresponding Author:}

Odeyemi Charity Segun,

Department of Electrical Electronics Engineering, Federal University of Technology, P. M. B 704, Akure, Nigeria.

Email: charityodeyemi@ymail.com

\section{All rights reserved.}

\section{INTRODUCTION}

As the world energy demand continues to increase, the world energy consumption is expected to reach about 25 terra watt within the next two decade. Solar energy is the primary and the most abundant of all the sources of electric energy generation. Therefore, harnessing solar energy for the generation of electricity using low cost materials and methods of production has become the main focus of researchers in the field of solar energy in recent years. Recently, many approach aimed at converting the abundant solar energy to electricity have been made to challenge the conventional silicon cell [1][2]. The titanium dioxide TiO2 dye sensitized solar cells (DSSCs) is viewed as having the prospect of substituting the silicon cell [2] [3]. DSSCs works by photo-excitation of dye received into the semiconductor - $\mathrm{TiO} 2$. The sensitizer received the incoming photons which in turn liberate electrons which traveled via semiconductor- TiO2 and the conductive substrate to the load. The dye which initially has been oxidized because of electron loss then regains its electron from an electrolyte which also got reduced by a conductor- graphite surface [4]. As shown in Figure 1, an electron was observed passing through a complete cycle of excitation, injection into the $\mathrm{TiO} 2$, traveled through the conducting surface of the electrode to the load, reduced by iodine at the counter electrode, diffusion in the electrolyte and regeneration of the oxidized dye. [5].

Through the DSSC technology, it is believed that the high cost which has been the major problem associated with the utilization of solar energy will be overcome [2]. Progress in the research findings in this field revealed a close resemblance in the natural photosynthesis and the way light photons are being 
harvested and transformed to electrical energy in DSSC [2]. From Figure 1, the photons are harvested at point (1) and this raise the dye molecule (which is the medium for photon reception) to its excited state (2) where electron is released through the semiconductor ( $\mathrm{TiO} 2)$ to the conducting surface of the working electrode (3). The liberated electron travels through the external load to the counter electrode (4). At point (5), the electron enters the electrolyte which in contact with the dye and the oxidized dye regains its electron back at point (6). As the electrolyte regenerates the dye, the electrolyte is also regenerated by the graphite coated counter electron and the cycle continues. The availability of the organic sensitizer which receives the light and the titanium dioxide which acts as the medium for transference of charges at very low cost are the main encouragement to researchers [1][6]. The main challenge in dye sensitized solar technology is the problem of short life span (of the order of few hours) because of degradation of the dye molecules due to dust and air infiltration, and excess UV absorption [7]. That is more electrons being lost than regain. A modified approach to DSSC fabrication was therefore used to achieve a stable performance.

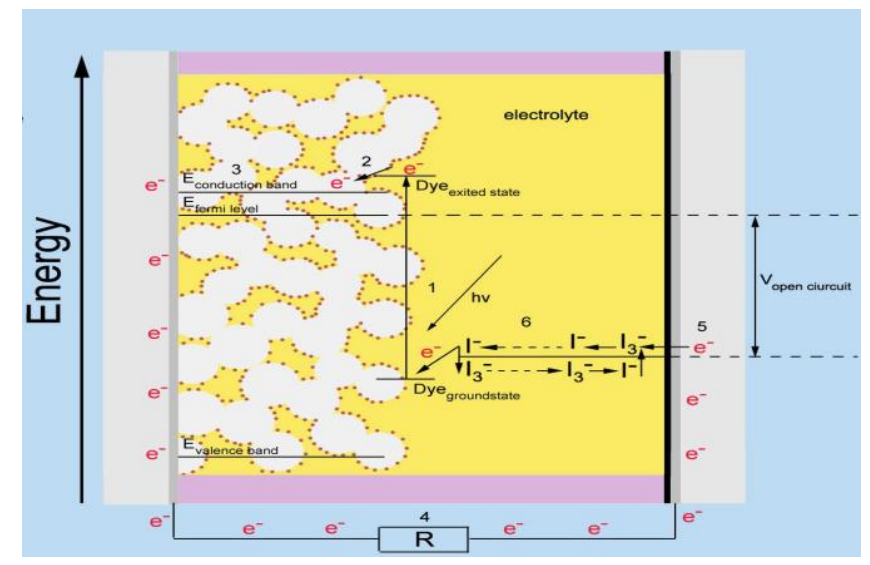

Figure 1. The complete cycle of a DSSC. [5]

\section{RESEARCH METHOD}

The components, mechanism and principles of dye sensitized solar cell were carefully studied. The materials were selected on their merits.

\subsection{The Electrodes}

DSSC uses two electrodes- the working or photo electrode and the counter electrode. Substrate for the working electrode must be such as allows the passage of light photons. When the electrons are liberated from the dye, the electrode must be of good conductivity to conduct these electrons through the load [8]. Therefore transparent conductive glass slide was used.

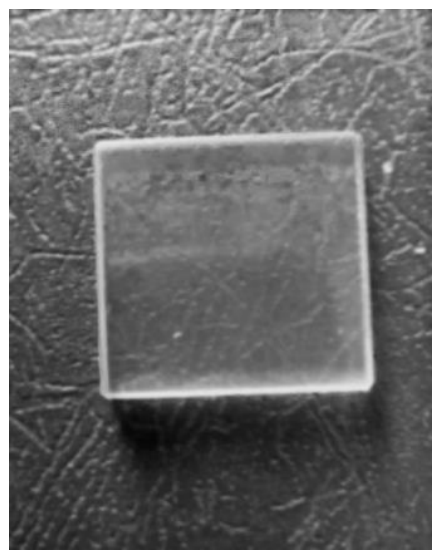

Figure 2. The transparent conductive glass 
The counter electrode though does not harvest photons but being a return part for the flowing electrons requires conductivity, thus transparent conductive glass for both electrode and counter electrode. A semiconductor is required to be deposited on the substrate of the working electrode, titanium dioxide $\mathrm{TiO} 2$ was used since research has proven that it has a higher photo harvesting efficiency than all other known semiconductors till date [9].

\subsection{The Sensitizer}

A dye is needed to absorb light photons. Organic dye sensitizers are mostly used, Teak (Tectonia Grandis) dye was obtained and used in this work.

\subsubsection{Teak (Tectonia Grandis) Dye}

The chemical and optimized structure of Tectonia Grandis dye (1,4,5,8-tetrahydro-2 isopentadienyl anthraquinone) are as shown.
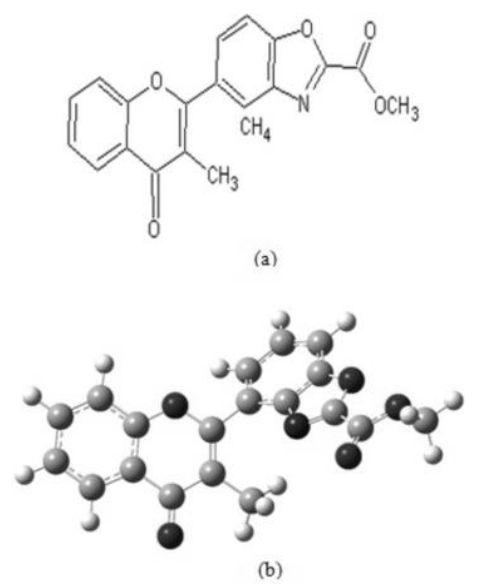

Figure 3. Teak (Tectonia Grandis) Dye (1,4,5,8- tetrahydro-2 isopentadienyl anthraquinone)

Chemical and (b) optimized structures [10]

\subsection{The Electrolyte}

Another important component of the dye sensitized solar cell DSSC is the electrolyte. The electrolyte is dissolved in an appropriate organic solvent and attracted into the intra-electrode space by capillary action. For this work potassium iodate KIO3 was used.

\subsection{The Mordant}

Mordant is a substance, usually inorganic metal oxide, which fixes or retains a dye on the host substance against fading due to excess and continuous UV light irradiation. Mordant is used to set colourants on fabrics or tissue sections, it develops a complex with the colourant which then holds fast to the material. It is used for dyeing in fabrics, and also in staining in cell or tissue preparations [11]. Copper sulphate was used as mordant in this work.

\subsection{The Method}

About $6 \mathrm{~g}$ of nanoparticle Titanium IV Oxide was mixed with $12 \mathrm{ml}$ of Acetic Acid in a mortar while grinding with pestle to break the aggregates and to produce a uniform and lump-free suspension. A drop of surfactant, like colourless detergents in $1 \mathrm{ml}$ of distill water was then added. The conductive side of the electrode substrate tested with a continuity tester then cleansed with ethanol and two third coated with the Titanium IV Oxide paste using Doctor Blade technique [8]. After deposition, it was annealed at about 450oC for 30 minutes.

The electrode is then placed faced down in a filtered dye and mordant solution and allows to soak the Titanium IV Oxide surface for about five minutes and then allowed to dry in a dark at room temperature. The conductive side of the counter-electrode was tested with continuity tester. The conductive surface was cleansed with ethanol, coated with graphite (optional) and gently placed face down on the Titanium IV Oxide coated part of the electrode so as to offset leaving one third uncoated conductive surface exposed on both the 
electrode and the counter electrode. They were then held firmly together with two alligator clips. One or two drops of the electrolyte were introduced at one edge of the slides and allowed to spread by capillary action, after which the edges cleansed and sealed with silicone adhesive to prevent excess air infiltration.

The assemblage was then tested with the electrode faced up for light photons collection as the positive terminal while the counter electrode will be the negative terminal connected to a digital multimeter. Two cells were made, one with the introduction of mordant and the edges sealed, while the other was basically on the known approach (without mordant and sealant).

\section{RESULTS AND ANALYSIS}

Two cells were fabricated, one with the known method (Gratzel method) while the other was made with the addition of a mordant and edges sealed. A highly sensitive and versatile Fluke digital multi-meter was used to measure the open-circuit voltage and short-circuit photocurrent of the DSSC as the cells were illuminated under a light intensity of $0.10 \mathrm{~W} / \mathrm{m} 2$, representing AM 1.5. The results are as shown in Table 1 and Figure 5.

From Table 1, using the same dye sensitizer on the two cells (one based on the conventional method while the other was based on the modified method), the summary of the solar cell parameters observed show that the addition of a mordant limits the fading effect of continuous irradiation and thus enhancing a steady photon harvesting. As observed in Figure 5, the sealant prevented air and dust infiltrations from reacting with the active components of the system. Therefore the cell was able to work for about 60 days compared to four hours life span of the other cell.

Table 1. Results of the Two Cells

\begin{tabular}{cccccccc}
\hline Dye & $\begin{array}{c}\text { Mode of } \\
\text { production }\end{array}$ & $\begin{array}{c}\text { Anne-aling } \\
\text { Temp. }\end{array}$ & $\begin{array}{c}\text { Voc } \\
\mathrm{mV}\end{array}$ & $\begin{array}{c}\text { Isc } \\
\mathrm{mA}\end{array}$ & FF & $\begin{array}{c}\text { Efficiency } \\
\boldsymbol{\eta}\end{array}$ & $\begin{array}{c}\text { Stability } \\
\text { Period }\end{array}$ \\
\hline Teak & $\begin{array}{c}\text { Staining with } \\
\text { dye only } \\
\text { Staining with } \\
\text { dye and } \\
\text { mordant and } \\
\text { edges sealed }\end{array}$ & $450 \mathrm{oC}$ & 36.00 & 0.18 & 0.99 & 0.06 & 4 hrs \\
& $450 \mathrm{oC}$ & 48.00 & 0.20 & 0.95 & 0.09 & 60 days \\
\hline
\end{tabular}

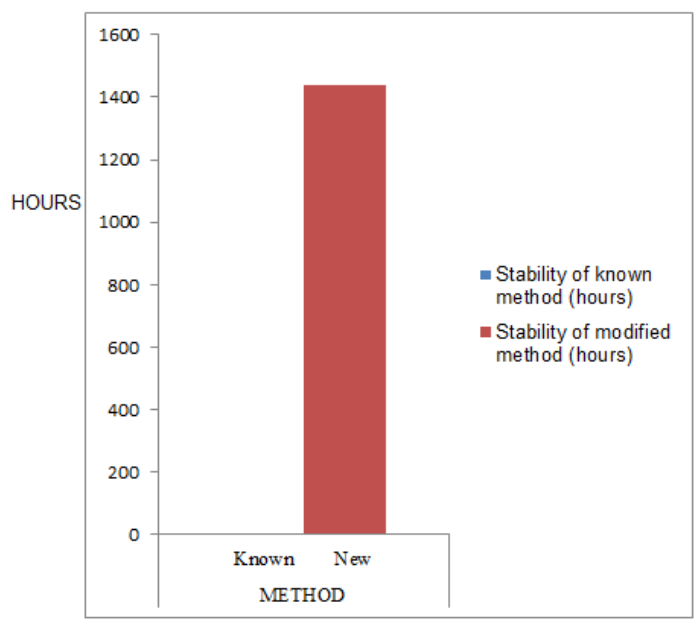

Figure 5. Chart representing the stability or active period of the two cells

The cell with mordant and sealed edges performed steadily for 60 days without degradation as shown in Table 1. Figure 5 shows the difference in the life span of the two cells, while the one made by the conventional method lasted for just four (4) hours the approach used in this study prolonged the life span to sixty (60) days. The addition of a mordant was observed to have fixed or retains the dye molecule on the semiconductor thus preventing fading due to continuous irradiation when the cell was being illuminated. This results in continuous photon harvesting and thus increasing the life-span of the cell. Sealing the edges of the cell also prevented dust particles and air infiltrations into the cell. According to Table 1, an increase in 
efficiency was also observed. This is as a result of fixing the dye against fading due to continuous light irradiation.

\section{CONCLUSION}

With the addition of copper sulphate as mordant to the Dye solution and sealing of the edges of the cells with silicone plastic sealant, the solar cell performance relatively stable when compared with existing ones. The solar cell parameters measured remain steady not just for few hours as recorded in the conventional method. In the first cell, an active period of about four hours was recorded. Even within the four hours, the open circuit voltage and the short circuit current measured were degrading gradually until almost zero. As seen in table 1 and figure 5, for 60 days (1440 hours) the short circuit current and the open circuit voltage remain constant. This stability can be attributed to mordant providing a type of shield, thus preventing excess UV light entering the cell and more importantly fixing the dye on the titanium dioxide. The infiltration of air which contains dust particles, water vapour and other atmospheric gases was also reduced by the sealing of the edges. Dust and air infiltration, dye fading and excess UV absorption have been found to be some of the major reasons for degradation causing instability in DSSC. Therefore, the active period of the cell increased from 4 hours to 60 days.

\section{REFERENCES}

[1] Ribeiro H.A., Sommeling P.M., Kroon J.M., Mendes A. and Costa C.A.V. Solar cells, International Journal of Green Energy, 2009, 6 245-256,.

[2] Gratzel M., Photochem J. Photobiology, Photochemistry Reviews, 2003, (4) 145-153.

[3] Gebeyehu D., Brabec C. J., and Sariciftci N. S. Thin Solid Films. 2002, 403, 271.

[4] Baxter Jason B. and Aydila Eray S. Nanowire-based dye-sensitized solar cells. Applied physics letters. 2005, 86, 053114 1-3

[5] Khalil Ebrahim Jasim. Dye Sensitized Solar Cells - Working Principles, Challenges and Opportunities. 2011, 3102.

[6] Chiba Y., Islam A., Watanabe Y., Komiya R., Koide N. and Han L. Electricity from Plants. Japanese Journal of Appl. Phys. 2006, (2) 45 638-640.

[7] Mehmood Umer, Rahman Saleem-ur, Harrabi Khalil, Hussein Ibnelwaleed A., and Reddy B. V. S. Advances in Dye Sensitized Solar Cells. Advances in Materials Science and Engineering, 2014, (3) 7, 204.

[8] Awodugba A. O. and Ilayas Abdul-Mojeed Olabisi. Fabrication of Dye Sensitized Solar Cell (DSSC) using ZnO Nanoparticles Synthesized from Zinc Nitrate Hexahydrate. Canadian Journal of Pure and Applied Sciences, Academic Publishers, British Columbia 2013, (7) 3 2635-2638.

[9] Zhang Q. and Cao G. Nano Today, 2011, 6 91-109.

[10] Han W. May, Ekanayake Piyasiri, Lim C. M. and Voo N. Y. Using Tectonia Grandis (TEAK) to generate electricity from sunlight. ARPN Journal of Engineering and Applied Sciences. 2015, (10) 16, 213.

[11] Adetuyi, O. A., Alaba, M. A., Ganiyu O., Akomolafe T., Odeyemi C. S. Natural Colourants of Yoruba Heritage in Nigeria - their multidimentional and durability potentials. The potentials of colouring plants of Yoruba heritage. International Edelstein Colour Symposium, Shekar College of Engineering and Design. Ramat Gan, Israel. 2011, 20321 